Volume 14. Nomor 1. June 2019 Page 57-72

\title{
Mewujudkan Desa Bebas Korupsi Melalui Pengelolaan Keuangan Desa Terpadu
}

\author{
Dewi Kania Sugiharti dan Ajie Ramdan ${ }^{{ }^{2}}$
}

Fakultas Hukum Universitas Padjadjaran, Indonesia

DOI: http://dx.doi.org/10.15294/pandecta.v14i1.16729

\section{Article info \\ Article History: \\ Received : December 2018 \\ Accepted: June 2019 \\ Published: June 2019}

\section{Keywords:}

village finance;

corruption;

village funds

\begin{abstract}
Abstrak
Artikel ini membahas masalah pengelolaan keuangan desa terpadu yang harus dilaksanakan oleh pemerintah desa untuk menghindari terjadinya korupsi. Hal tersebut penting untuk memahami permasalahan pengelolaan keuangan desa yang terjadi. Metode penelitian yang digunakan yakni metode penelitian yang bersifat yuridis-normatif dengan mengambil contoh kasus korupsi pengelolaan dana desa di Simalungun, Mojokerto, Magetan, dan Ciamis. Hasil penelitian menunjukkan bahwa keuangan desa adalah termasuk keuangan negara. Pasal 93 ayat (1) PP No. 43 Tahun 2014 tentang Peraturan Pelaksana UU No. 6 Tahun 2014 tentang Desa menentukan Perencanaan, Pelaksanaan, Penatausahaan, Pelaporan dan Pertanggungjawaban harus dilakukan dalam mengelola keuangan desa terpadu. Pengelolaan keuangan desa terpadu menurut Kerugian keuangan negara yang terjadi di empat desa tersebut merupakan kesalahan pengelolaan keuangan negara. Asas pengelolaan keuangan desa yaitu transparansi, akuntabilitas dan partisipatif harus diterapkan oleh pemerintahan desa dalam pengelolaan keuangan desa untuk mencegah terjadinya kerugian keuangan negara. Risiko keuangan desa yang diprediksikan oleh BPKP berpotensi mengakibatkan kerugian keuangan negara. Prediksi tersebut seharusnya ditindaklanjuti dengan memperketat sistem pengawasan kepada kepala desa serta perangkatnya dalam mengelola keuangan desa, kerja sama beberapa kementerian diantaranya Kementerian Keuangan, Kementerian Desa dan Transmigrasi, Kementerian Dalam Negeri, dan perlu dilakukan untuk mencegah terjadinya kerugian keuangan negara.
\end{abstract}

\begin{abstract}
This article discusses the problem of integrated village financial management that must be carried out by the village government to avoid corruption. This is important to understand the problems of village financial management that occur. The research method used is a juridical-normative research method by taking examples of corruption cases of village fund management in Simalungun, Mojokerto, Magetan and Ciamis. The results of the study show that village finance is part of state finance. Because regional finance is a part of state finance. Integrated village financial management based on Article 93 paragraph (1) of Government Regulation Number 43 of 2014 concerning Implementing Regulations Law Number 6 Year 2014 concerning Villages includes Planning, Implementation, Administration, Reporting and Accountability. The state financial losses that occurred in the four villages constituted a mistake in managing state finances. The principle of village financial management, namely transparency, accountability and participatory must be applied by the village government in managing village finance to prevent the loss of state finances. Village financial risks predicted by the BPKP have the potential to result in state financial losses. The prediction should be followed up by tightening the supervision system to the village head and its instruments in managing village finance, coordination between the finance ministries, the interior ministry and village ministries \& transmigration needs to be done to prevent the loss of state finances.
\end{abstract}




\section{Pendahuluan}

Indonesia memiliki sekitar 73.000 desa dan perkiraan 8.000 kelurahan. Desa-desa terdiri dari desa biasa dan desa adat. Dalam hal ini dua konsep masyarakat dibedakan satu dengan lainnya, yaitu masyarakat desa dan masyarakat adat. Asal muasal desa adalah masyarakat dengan mempunyai pemerintahan sendiri antara lain nagari, marga, dan yang lain berdasarkan Pasal 18B ayat (2) Undang-Undang Dasar 1945 diategorikan sebagai kesatuan masyarakat hukum adat (Asshiddiqie, 2015: 353).

Menurut UU No. 6 Tahun 2014 tentang Desa, keberadaan desa merupakan bagian dari pemerintahan daerah dan peraturan desa menegaskan menjadi dari pengertian peraturan perundang-undangan, oleh karena itu desa menjadi perpanjangan tangan terakhir dari berbagai fungsi pemerintahan negara. Kebijakan penting dalam Undang-Undang No. 6 Tahun 2014 tentang Desa, sistem pemerintahan desa adalah tentang struktur pemerintahan negara yang merupakan sistem hukum terintegrasi. Desa dari sudut pandang administrasi pemerintahan terbawah dan komunitas politik. Struktur pemerintahan desa anatara lain fungsi eksekutif, legislatif, pemilihan kepala desa. Dalam hal ini Desa dan masyarakat desa sebagai miniatur politik dan administrasi pemerintahan, permasalahan yang terjadi adalah aspek kesejahteraan kurang diperhatikan. Badan usaha milik desa yang mempunyai fungsi menyumbang pendapatan desa (Asshiddiqie, 2015: 367-372).

Undang-Undang No. 6 Tahun 2014 tentang Desa meregulasi pendapatan desa, yaitu terdiri dari pendapatan asli desa, perimbangan keuangan pusat dan daerah, bagi hasil pajak daerah dan retribusi daerah Kabupaten/Kota alokasi anggaran dari APBN, anggaran berasal dari APBN, anggaran berasal dari APBD Kabupaten/Kota, sumbangan yang tidak mengikat dari pihak ketiga. Anggaran berasal dari APBD Provinsi dan APBD Kabupaten/Kota kepada Desa diberikan dengan pertimbangan keuangan Pemerintahan Daerah. Anggaran yang diberikan peruntukannya dalam mempercepat pembangunan desa. Pendapat desa lainnya diperoleh dari
Badan Usaha Milik Desa, tambang mineral bukan logam dan tambang batuan tidak memakai peralatan berat, tidak diperdagangkan. Anggaran berasal dari perimbangan Pemerintah Daerah kabupaten/ Kota paling sedikit 10\% (sepuluh persen) kemudian dikurangi dari dana yang dialokasi secara khusus disebut anggaran khusus untuk Desa. Anggaran untuk Desa berasal dari APBN Pusat bertujuan menggerakan program Desa dengan merata dan adil (Asshiddiqie, 2015: 372373).

Pendapatan Desa tersebut adalah bagian dari keuangan negara. Pengertian keuangan negara menurut UU No. 17 Tahun 2003 adalah semua hak dan kewajiban negara yang dapat dinilai dengan uang, serta segala sesuatu baik berupa uang maupun berupa barang yang dapat dijadikan milik negara berhubung dengan pelaksanaan hak dan kewajiban tersebut. Sumber operasional melaksanakan perintah negara bisa dipahami sebagai definisi keuangan negara (Saidi, 2008: 9). Untuk mencapai cita-cita negara akan selalu berhubungan dengan keuangan negara sebagai bentuk pemberian anggaran negara kepada pelaksanaan pemerintahan negara yang dilaksakan oleh aparat negara. Tanpa anggaran negara, tujuan pokok negara tidak bisa diwujudkan dan hanya angan-angan saja. Pengelolaan anggaran negara merupakan bagian dari pelaksanaan pemerintahan negara. Dalam hal ini termasuk pengelolaan keuangan desa (Saidi, 2008: 8).

Kesalahan pengelolaan keuangan negara mengakibatkan anggaran negara menjadi tidak sesuai sasarannya sehingga mengakibatkan kerugian keuangan negara. Kelalaian mengelola anggaran negara dan kesalahan yang dilakukan karena sengajaan melakukan. Perbuatan ini dilarang keras terjadi supaya tidak terjerat hukum. Dalam hal ini tidak sebagai subjek hukum yang berkewajiban melakukan hak dan kewajiban (Saidi, 2008:71).

Penegakan hukum di Indonesia dengan memperhatikan semakin meningkatnya perkara pidana, khususnya pidana korupsi, yang diajukan ke pengadilan dengan dasar adanya kerugian keuangan negara. Adanya perkembangan dalam penangangan perkara 
pidana korupsi tersebut tidak terlepas dari pengetahuan pihak penuntut umum yang mendorong terciptanya suatu simpulan perbuatan seseorang yang melakukan perbuatan melanggar hukum dalam melaksanakan kewenangannya (Atmadja, 2008: 90). Apabila hal ini terjadi dalam pengelolaan keuangan desa dan menimbulkan kerugian keuangan negara, sebaiknya diberikan solusi terhadap pengelolaan keuangan desa yang bersih dari korupsi. Sampai akhir tahun 2017, terdapat 900 kasus kepala desa berhadapan dengan hukum karena anggaran desa. Sebagian kepala desa harus menghadapi penjara karena anggaran desa. Dari 900 kasus tersebut ini diprediksi akan semakin meningkat, karena aparat pemerintah sulit mengawasi 74.000 desa di Indonesia. Permasalahan lainnya adalah Perangkat desa belum menguasai pelaporan dana desa sesuai regulasi. Penyalahgunaan dana desa karena korupsi paling banyak terjadi. Komisi Pemberantasan Korupsi (KPK) memprediksi, modus operandi penyalahgunaan dana desa mempunyai tindakan serupa sebagai contoh mark up dana desa, masyarakat tidak dilibatkan untuk bermusyawarah, penyelewenangan dana desa untuk kepentingan pribadi, dan pengadaan barang dan jasa fiktif..

Berdasarkan permasalahan yang dikemukakan, oleh karena itu, artikel ini berfokus pada 2 (dua) rumusan masalah yaitu, sebagai berikut: Bagaimana pengaturan dan pengelolaan keuangan desa dalam perspektif hukum keuangan negara? Dalam hal terjadi kesalahan pengelolaan keuangan desa, apakah hal tersebut termasuk ruang lingkup kerugian keuangan negara?

\section{Metode Penelitian}

Peneliti menggunakan pendekatan penelitian yang digunakan adalah yuridis normatif. Yuridis normatif adalah penelitian yang dilakukan dengan meneliti bahan pustaka atau data sekunder sebagai bahan dasar untuk diteliti dengan cara melakukan penelusuran terhadap peraturan-peraturan dan literatur-literatur yang berhubungan dengan permasalahan yang diteliti (Soekanto, 2006: 13). Berdasarkan permasalahan yang diteliti, penelitian ini merupakan penelitian hukum (legal research).

Pendekatan perundang-undangan (statute research), digunakan untuk meneliti, mendalami, dan menelaah beberapa peraturan perundang-undangan tentang pengelolaan keuangan desa. Karena fokus dan tema sentral penelitian adalah Aspek Hukum Pengelolaan Keuangan Desa, maka akan diteliti dan ditelusuri berbagai aturan tentang UU No. 6 Tahun 2014 dan UU No. 17 Tahun 2003 serta analisis kasus korupsi pengelolaan dana desa di Simalungun, Mojokerto, Magetan, dan Ciamis.

\section{Hasil dan Pembahasan}

\section{Pengaturan dan Pengelolaan Keuangan Desa Dalam Perspektif Hukum Keuangan Negara}

Ruang Lingkup Keuangan Negara Menurut Pasal 23 UUD 1945

Keuangan Negara merupakan urat nadi negara. Karena tanpa uang, negara tidak bisa menjalankan kehidupannya. Keuangan negara ini dituliskan dalam Anggaran Pendapatan dan Belanja Negara (APBN) (Atmadja, 2009: 54).

Hakikat atau falsafah APBN menurut Rene Stourm sebagai berikut (Atmadja, 2009: 54):

"The constitutional right which a nation possesses to authorize public revenue and expenditures does not originates from the fact that the members of the nation contribute the payments. This right is based on a loftier idea. The idea of sovereignty."

Pendapat Rene Stourm diterjemahkan ke dalam bahasa Indonesia sebagai berikut:

Hak konstitusional yang dimiliki suatu negara untuk mengesahkan pendapatan dan pengeluaran publik tidak berasal dari fakta bahwa anggota bangsa berkontribusi dalam pembayaran. Hak ini didasarkan pada ide yang lebih tinggi. Gagasan kedaulatan.

Public revenue and expenditure APBN inti dari kedaulatan. Jika kedaulatan berada pada raja, sehingga raja berwenang menentukan APBN tersebut. Negara republik Indo- 
nesia adalah negara demokratis dan berkedaulatan rakyat. Pasal 1 ayat (2) UUD 1945 menentukan Kedaulatan berada di tangan rakyat dan dilaksanakan menurut UndangUndang Dasar. Di Negara Republik Indonesia caranya rakyat sebagai bangsa akan hidup, harus ditetapkan oleh rakyat itu sendiri dengan Undang-Undang. Rakyat menentukan nasibnya sendiri, sehingga cara hidupnya yang tercermin dalam APBN (Atmadja, 2009: 54).

Di dalam Pasal 23 ayat (1) UUD 1945 ditetapkan sebagai berikut:

"Anggaran pendapatan dan belanja Negara sebagai wujud dari pengelolaan keuangan Negara ditetapkan setiap tahun dengan undangundang dan dilaksanakan secara terbuka dan bertanggung jawab untuk sebesar-besarnya kemakmuran rakyat."

Sumber hakikat APBN adalah kedaulatan. Kedaulatan negara tertingggi di Republik Indonesia berada di tangan rakyat. Kewenangan untuk menentukan APBN dilimpahkan kepada DPR dan Pemerintah (Atmadja, 2009: 55).

Pasal 23 ayat (2) UUD 1945 menentukan sebagai berikut:

"Rancangan undang-undang anggaran pendapatan dan belanja Negara diajukan oleh Presiden untuk dibahas bersama Dewan Perwakilan Rakyat dengan memperhatikan Dewan Perwakilan Daerah."

Pasal 23 ayat (3) UUD 1945 menentukan sebagai berikut:

"Apabila Dewan Perwakilan Rakyat tidak menyetujui rancangan anggaran pendapatan dan belanja negara yang diusulkan oleh Presiden, Pemerintah menjalankan Anggaran Pendapatan dan Belanja Negara tahun yang lalu."

Pemerintah baru dapat menjalankan APBN setelah mendapat persetujuan dari DPR dengan undang-undang, persetujuan yang diberikan oleh DPR, kewenangan DPR mempunyai kedaulatan dalam melakukan budgeting, kewenangan DPR menyetujui APBN sepenuhnya menjadi kewenangan DPR (Atmadja, 2009: 54).

Pendapat yang menyatakan pada intinya APBN itu adalah machtiging antara lain
D. Simons yang menyatakan sebagai berikut (Atmadja, 2009: 55-56):

"Elk begrotingshoofdatuk wordt bij afzonderlijke wet vastgesteld. De wetsontwerpen zijn voor de Regeering middle tot de verkriging van de autorisatie van de volksvertegenwoordiging om vitgeven tot bepaalde maxima te doen, daardoor ook om maatregelen te troffen welke vitgaven eisen."

Pendapat D. Simons diterjemahkan ke dalam bahasa Indonesia sebagai berikut:

"Setiap bab anggaran ditentukan oleh undangundang terpisah. Bagi Pemerintah, rancangan undang-undang adalah otorisasi perwakilan rakyat melakukan pembiayaan sejumlah maksimal tertentu dari anggaran, dengan demikian juga untuk mengambil langkah-langkah yang memerlukan pembiayaan."

Dengan demikian, titik berat tujuan anggaran negara adalah mengenai "autorisatie" dari "volksvertegenwoordiging" kepada pemerintah memberikan pembiayaan maksimal anggaran tertentu. Apabila pemerintah menggunakan APBN dalam melaksanakan kewenangannya, tindakan tersebut merupakan machtiging yang memerlukan tanggung jawab. Tanggung jawab tersebut harus diserahkan kepada yang berwenang memberikan machtiging. UUD 1945 machtiging diserahkan oleh DPR terhadap pemerintah agar dikerjakan sebagaimana mestinya, sehingga pemerintah harus mempertanggungjawabkan dihadapan DPR (Atmadja, 2009: 55-57).

Anggaran Pendapatan dan Belanja Negara (APBN) merupakan instrumen pemerintah untuk memberikan kesejahteraan kepada rakyatnya dan juga sebagai tindakan pemerintah untuk mengelola perekonomian negara. APBN bukan hanya tentang kebijakan ekonomi, tetapi juga tentang political decision. DPR memiliki hak membentuk undang-undang, menganggarkan APBN, dan mengawasi APBN, dengan tujuan APBN bisa digunakan secara efisien menjadi alat yang berfungsi untuk memakmurkan rakyat dan menyelenggarakan perekonomian negara dengan baik. Bertujuan menyelenggarakan good governance dalam pemerintahan negara, pemerintah melakukan reformasi manajemen keuangan pemerintah sejak beberapa tahun yang lalu. Pengesahan Undang-undang 
Nomor 17 Tahun 2003 tentang Keuangan Negara, Undang-undang Nomor 1 Tahun 2004 tentang Perbendaharaan Negara, dan Undang-undang Nomor 15 Tahun 2004 tentang Pemeriksaan Pengelolaan dan Tanggung jawab Keuangan Negara adalah reformasi yang dilakukan merupakan landasan hukum yang kuat (Muin, 2014:75). Oleh karena itu, Ruang lingkup keuangan negara adalah uang yang berasal dari Anggaran Pembelanjaan Negara (APBN) yang berfungsi untuk memakmurkan rakyat dan hal tersebut merupakan kebijakan pemerintah untuk mengelola perekonomian negara.

\section{Ruang Lingkup Keuangan Negara Menurut Undang-Undang No. 17 Tahun 2003}

Berdasarkan Undang-Undang No. 17 Tahun 2003 tentang Keuangan Negara, memperluas pengertian keuangan Negara adalah semua hak dan kewajiban negara yang dapat dinilai dengan uang, serta segala sesuatu, baik berupa uang maupun berupa barang yang dapat dinilai dengan uang, serta segala sesuatu, baik berupa uang maupun berupa barang yang dapat dijadikan milik negara berkaitan dengan pelaksanaan hak dan kewajiban tersebut. Anggaran pendapatan dan belanja negara, anggaran pendapatan dan belanja daerah dan keuangan negara yang terdapat BUMN atau BUMD adalah Keuangan Negara dalam arti luas. Akan tetapi, setiap badan hukum dan dipertanggungjawabkan sendiri-sendiri adalah keuangan negara dalam arti sempit (Saidi, 2008: 2-3).

Berdasarkan objek, anggaran negara terdiri dari hak dan kewajiban negara bisa dinilai dengan uang, kegiatan dan kebijakan dalam perpajakan merupakan bagian dari keuangan negara, moneter dan pemanfaatan kekayaan negara yang dipisahkan, berbagai macam kekayaan berupa uang, barang yang dapat dijadikan milik negara yang berkaitan dengan pelaksanaan hak dan kewajiban tersebut. Berdasarkan subjek, keuangan negara terdiri dari seluruh objek seperti disebut diatas merupakan milik negara dan dikuasai oleh pemerintah pusat, pemerin- tah daerah, perusahaan negara/daerah, badan lain yang berhubungan dengan anggran negara. Berdasarkan proses, keuangan negara terdiri dari semua kegiatan yang berhubungan dengan pengurusan objek seperti disebutkan diatas mulai dari merumuskan kebijakan dan mengambil keputusan kemudian diakhiri dengan pertanggungjawaban. Berdasarkan tujuan, keuangan negara terdiri dari seluruh kebijakan, hubungan hukum, kegiatan yang berhubungan dengan kepemilikan dan/atau pemilikan objek sebagaimana tersebut diatas untuk melaksanakan pemerintahan negara (Saidi, 2008: 3-4).

Ruang lingkup keuangan negara menurut Undang-Undang Nomor 17 Tahun 2003 meliputi hak negara mengambil pajak, mengeluarkan dan menerbitkan uang dan melakukan pinjaman, kewajiban negara mengadakan pelayanan umum negara kemudian memberikan bayaran tagihan pihak ketiga, pengeluaran negara, income negara, income daerah, pengeluaran daerah, kekayaan negara juga kekayaan daerah yang diselenggarakan secara mandiri atau oleh pihak lain berupa uang, surat berharga, piutang barang, dan hak-hak lain yang dapat dinilai dengan uang termasuk kekayaan terpisah pada perusahaan negara/perusahaan daerah. Pemerintah menyelenggarakan pemerintahan dan/ atau kepentingan umum, kekayaan pihak lain diperoleh dengan penggunaan fasilitas pemerintah (Sumbu, 2010: 576).

Berdasarkan Pasal 3 Undang-undang No. 17 Tahun 2003 Tentang Keuangan Negara, beberapa prinsip-prinsip pengelolaan keuangan negara antara lain, tertib, taat pada peraturan perundang-undangan, efisien, ekonomis, efektif, transparan, dan bertanggung jawab dengan mempertimbangkan keadilan dan kepatutan. Tertib, penggunaan keuangan negara memperhatikan tertib administrasi dan operasional dengan berkesinambungan. Taat kepada peraturan perundang-undangan, artinya penggunaan anggaran negara harus berdasarkan pada peraturan perundang-undangan yang berlaku. Efisien, artinya penggunaan keuangan negara secara hemat dan sesuai peruntukannya. Ekonomis, artinya 
penggunaan anggaran negara dengan mempertimbangkan terbatasnya uang negara berdasarkan pengalokasian sesuai dengan kebutuhan. Efektif, dalam hal ini pengelolaan uang negara harus sesuai dengan arah tujuan pembangunan. Transparan, penggunaan uang negara harus dilakukan secara terbuka dengan mempublikasikan laporan keuangan berdasarkan regulasi yang berlaku. Bertanggungjawab, dalam hal ini setiap rupiah uang negara yang dikeluarkan dari anggaran negara harus bisa mempertanggungjawabkan kepada masyarakat berdasarkan regulasi yang berlaku dengan memperhatikan rasa keadilan dan kepatutan, pengelolaan keuangan negara harus mempertimbangkan keadilan masyarakat, wilayah, dan bisa juga berdasarkan norma yang berlaku di masyarakat.

\section{Ruang Lingkup Keuangan Desa}

Keuangan bersumber dari kata monetary, sedangkan kata finance berarti pembiayaan. Keuangan Negara dihubungkan dengan public finance. Finance atau pembiayaan adalah aktivitas yang berhubungan dengan uang negara. Padmo Wahyono mendefinisikan keuangan negara yaitu APBN "plus" dikatakan bahwa (Asshiddiqie, 2008: 810):

\begin{abstract}
"APBN adalah anggaran pendapatan dan belanjanya pemerintah pusat. Kekayaan Negara yang dipisahkan untuk mendirikan perusahaan milik Negara bukanlah pengeluaran konsumtif melainkan pengeluaran produktif yang diusahakan untuk menjadi sumber pendapatan baru bagi APBN. Dengan perkataan lain, meskipun dipisahkan dari APBN, namun dalam waktu tertentu dan secara berangsurangsur diharapkan dapat 'bergabung' kembali. APBN diadakan berdasarkan atas kuasa undang-undang yang membagi wilayah Negara kesatuan kita menjadi daerah-daerah otonom Demikian juga kedudukan perusahaan daerah terhadap APBD adalah serupa dengan kedudukan perusahaan milik pusat terhadap APBN"
\end{abstract}

Jimly Asshiddiqie berpendapat keuangan daerah sebenarnya adalah juga keuangan negara. Desa yang merupakan pemerintahan terbawah dalam pemerintahan Indonesia memiliki sistem keuangan tersendiri terintegrasi ke dalam pendapatan asli desa yang merupakan bagian dari APBN (Asshiddiqie, 2008: 813).

Pendapatan desa terdiri dari tujuh ba- gian antara lain pendapatan asli desa, alokasi APBN, bagian dari PDRD kabupaten/kota, alokasi dana desa (ADD),bantuan keuangan dari APBD Provinsi/Kabupaten/kota, hibah, sumbangan pihak ketiga, pendapatan sah lainnya.

Dengan tujuh pendapatan desa tersebut, dana desa (DD) merupakan sumber pendapatan paling strategis untuk pendapatan desa. Undang-Undang No. 6 Tahun 2014 tentang Desa mengatur tentang pendapatan desa yaitu desa memiliki sumber penghasilan yang terdiri atas pendapatan asli desa, bagi hasil pajak daerah dan retribusi daerah Kabupaten/Kota, bagian dari dana perimbangan keuangan pusat dan daerah yang diterima oleh Kabupaten/Kota, alokasi anggaran dari APBN, bantuan keuangan dari APBD Provinsi dan APBD Kabupaten/Kota, hibah atau sumbangan yang tidak mengikat berasal dari pihak ketiga. Bantuan keuangan diperoleh dari APBD Provinsi dan APBD Kabupaten/ Kota kepada Desa diberikan sesuai dengan keadaan keuangan Pemerintah Daerah. Bantuan tersebut diperuntukan mempercepat Pembangunan Desa. Sumber pendapatan lainnya yang bisa diusahakan oleh Desa berasal dari BUMD, pengelolaan pasar Desa, pengelolaan kawasan wisata skala Desa, pengelolaan tambang mineral bukan logam dan tambang batuan tanpa menggunakan alat berat, dan sumber lainnya bukan untuk diperjualbelikan. Bagian dari dana perimbangan yang diterima Pemerintah Daerah Kabupaten/Kota paling sedikit 10\% setelah dikurangi dana alokasi khusus (DAK) kemudian disebut alokasi dana desa (ADD). Alokasi anggaran untuk Desa bersumber dari belanja pusat dilakukan untuk menggerakan program desa secara merata dan berkeadilan (Asshiddiqie, 2015: 372-373).

Dana bantuan langsung dipergunakan kepada Pemerintah Desa dalam meningkatkan sarana pelayanan masyarakat, kelembagaan dan prasarana desa yang diperlukan untuk menjadi pilihan utama untuk masyarakat, pemanfaatan dan administrasi pengelolaannya dilakukan dan dipertanggung jawabkan oleh Kepala Desa adalah ADD. Menyelenggarakan urusan pemerintahan, dalam hal 
ini tentang pengaturan kehidupan masyararakat berdasarkan kewenangan desa seperti pembuatan peraturan desa dan membentuk lembaga kemasyarakatan juga pemberdayaan masyarakat dalam penyediaan sarana prasarana fasilitas umum adalah Tugas dari kepala desa. Bidang kemasyarakatan kepala desa adalah memberdayakan masyarakat dalam rangka membina sosial budaya masyarakat. Berdasarkan kewajiban tersebut, pertanggungjawaban kepala desa harus dibuat dengan membuat laporan kegiatan pemerintahan desa kemudian menyerahkan kepada Bupati/Walikota, dan laporan pertanggungjawaban untuk BPD. Kepada publik harus menyampaikan laporan penyelenggaraan pemerintahan kepada masyarakat (Paratama, 2018: 34).

APBN merupakan sumber pendanaan utama dana desa yang diberikan untuk desa. Pemerintah pusat menyerahkan dengan transfer kepada APBD kabupaten atau kota diperuntukan untuk pendanaan kegiatan pemerintahan, implementasi kegiatan pembangunan, juga membina dan memberdayakan masyarakat. Untuk meningkatkan kehidupan yang berkualitas atau peningkatan kesejahteraan masyarakat pedesaan adalah prioritas pembangunan desa. Pemberdayaan masyarakat desa adalah upaya untuk mengembangkan kemandirian dan kesejahteraan masyarakat dengan peningkatan pengetahuan, perilaku, kesadaran, sikap, keterampilan, kemampuan, serta pemanfaatan sumber daya dengan menetapkan kegiatan, program, dan kebijakan, juga pendampingan yang disesuaikan dengan esensi permasalahan dan prioritas kebutuhan masyarakat desa. Dana desa digunakan untuk pembangunan dan pemberdayaan masyarakat desa. Prioritas bagi pembangunan desa dengan cara pengalokasian dana desa untuk meningkatkan kualitas hidup juga kesejahteraan. Kemampuan mengatasi kemiskinan untuk pemenuhan standar kehidupan masyarakat, pembangunan fasilitas masyarakat, pengembangan ekonomi unggulan setempat, dan pemeliharaan sumber daya alam dan lingkungan dengan berkesinambungan. (Meutia, 2017: 339). Oleh karena itu, ruang lingkup keuangan desa berdasarkan pendapat Padmo Wahyono dan
Jimly Asshiddiqie, keuangan desa sebagai pemerintahan paling kecil dalam pemerintahan Indonesia mempunyai sistem keuangan independen yang terintegrasi ke dalam pendapatan original desa yang tidak terpisahkan dari APBN. Sumber pembiayaan utama dana desa diperoleh dari transfer dari APBD kabupaten/kota oleh pemerintah pusat. Dana tersebut digunakan oleh desa untuk pendanaan menyelenggarakan pemerintahan, pelaksanaan pembangunan, serta pembinaan dan pemberdayaan masyarakat.

\section{Pengelolaan Keuangan Desa}

Keuangan desa, peraturan awalnya adalah Peraturan Menteri Dalam Negeri No. 113 Tahun 2014 tentang Pengelolaan Keuangan Desa. Permendagri mempermudah dalam mengelola keuangan desa supaya tidak menimbulkan berbagai macam tafsir untuk implementasinya. Desa bisa mewujudkan pengelolaan keuangan yang efektif dan e\sien. Harapannya akan mewujudkan pengelolaan pemerintahan desa yang bagus berdasarkan parameter dalam hal ini transparan, akuntabel dan partisipatif. Dalam hal ini, regulasi menyusun APBDesa berdasarkan Permendagri tersebut akan menerangkan pertanggungjawaban seseorang, dan bertanggung jawab kepada siapa, dan pertanggungjawaban tersebut bagaimana mekanismenya. Pemerintah pusat harus menetapkan pedoman umum mekanisme pemerintah desa melaporkan dan mempertanggungjawabankan pelaksanaan pemerintah desa berdasarkan Permendagri No. 35 Tahun 2007. (Khoiriah, 2017: 24).

Pengertian keuangan desa menurut Undang-Undang Nomor 6 Tahun 2014 tentang Desa adalah seluruh hak dan kewajiban desa dinilai dengan uang serta segala sesuatu berupa uang dan barang yang berhubungan dengan pelaksanaan hak dan kewajiban desa. Undang-Undang Nomor 6 Tahun 2014 tentang Desa dan peraturan pelaksananya, menentukan kepala desa adalah pemegang kewenangan untuk pengelolaan keuangan desa. Kepala desa mendelegasikan sebagian kewenangan tersebut kepada perangkat desa berdasarkan Pasal 75 ayat (2). Berdasarkan Pasal 93 ayat (1) PP No. 43 Tahun 2014 ten- 
tang Peraturan Pelaksana UU No. 6 Tahun 2014 tentang Desa Pengelolaan keuangan desa terpadu meliputi Perencanaan, Pelaksanaan, Penatausahaan, Pelaporan dan Pertanggungjawaban.

Berdasarkan penelusuran dari hulu, pengelolaan keuangan desa terpadu berawal dari perencanaan. Pertama kali musyawarah desa yang dilaksanakan oleh Badan Permusyawaratan Desa (BPD) dengan tujuan mendiskusikan kegiatan strategis. Selanjutnya permusyawaratan desa tentang merencanakan pembangunan desa dilanjutkan dengan bermusyawarah pembangunan perencanaan desa dilaksanakan kepala desa dan perangkatnya. Musyawarah tersebut terkait Rencana Kerja Pemerintah Desa (RKPDes) serta APBDes setiap setahun sekali dan Rencana Pembangunan Jangka Menengah Desa (RPJMDes) setiap enam tahun sekali (Khoiriah, 2017: 26-27).

Pelaksanaan pengelolaan keuangan yang dilakukan di desa harus berdasarkan Permendagri Nomor 113 Tahun 2014. Seluruh pengeluaran dan penerimaan desa harus menggunakan rekening desa, dan dilengkapi dengan dokumen yang sah. Pengajuan kegiatan disertai dengan Rancangan Anggaran Biaya (RAB) diverifikasi dan disahkan oleh sekretaris desa. Semua kegiatan diwajibkan menggunakan buku bantuan kas. Apabila pelaksanaan pengelolaan keuangan sudah sesuai dengan Permendagri Nomor 113 Tahun 2014, hal tersebut dapat disimpulkan sudah baik karena telah mematuhi prinsip dasar pengelolaan keuangan. Penatausahaan berhubunga dengan aspek penatausahaan, dua hal yang harus dilakukan adalah penggunaan buku kas dan laporan pertanggungjawaban. Berkenaan dengan buku kas, desa harus memiliki Buku Bank, Buku Kas Pembantu Pajak, dan Buku Kas Umum. Buku Kas terkait laporan pertanggungjawaban bendahara desa. Pelaporan dan pertanggungjawaban terkait dengan pelaporan kepala desa memiliki kewajiban untuk penyampaian laporan realisasi dalam pelaksanaan APBDesa kepada Bupati atau Walikota terdiri dari laporan realisasi pelaksanaan APBDesa semester pertama dan semester akhir (Meutia, 2016: 347).

Pengelolaan keuangan desa tidak ter- pisahkan dari keuangan negara harus sesuai regulasi yang telah ditentukan oleh negara. Perencanaan, Pelaksanaan, Penatausahaan, Pelaporan dan Pertanggungjawaban adalah Pengelolaan keuangan desa terpadu yang diatur dengan Pasal 93 ayat (1) PP No. 43 Tahun 2014 tentang Peraturan Pelaksana Undang-Undang Nomor 6 Tahun 2014 tentang Desa meliputi Pelaksanaannya pengelolaan keuanga desa berdasarkan Permendagri Nomor 113 Tahun 2014 seluruh pengeluaran dan penerimaan desa wajib menggunakan rekening desa, dan dilengkapi dokumen yang sah. Pengajuan kegiatan harus disertakan dengan Rancangan Anggaran Biaya (RAB). Kemudian diverifikasi dan disahkan oleh sekretaris desa. Semua kegiatan wajib menggunakan buku bantuan kas. Apabila pelaksanaan pengelolaan keuangan sudah berdasarkan Permendagri Nomor 113 Tahun 2014, hal tersebut sudah dilaksanakan dapat disimpulkan sudah baik karena telah mematuhi prinsip dasar pengelolaan keuangan negara.

\section{Pengawasan Pembangunan Desa}

Pelaksanaan Pembangunan Desa harus dilakukan Pengawasan. UU No. 6 Tahun 2014 tentang Desa memberikan dasar menyelenggarakan, mengawasi dan memantau pembangunan desa terdiri dari pengawasan dari lembaga desa dan publik dan pengawasan oleh supra-desa (Khoiriah, 2017: 25).

Pasal 26 Peraturan Pemerintah No. 60 Tahun 2014 menentukan Pengawasan supra desa secara bertahap yang dilakukan pemerintah kabupaten/kota. Pemerintah pusat dilakukan Kementerian Dalam Negeri RI, Kementerian Desa RI dan Kementerian Keuangan RI. Pelaksanaannya, pengawasan yang dilaksanakan kabupaten/kota merupakan tanggung jawab bupati/walikota yang diserahkan kepada camat dan Inspektorat Kabupaten/Kota. Pemerintah Kabupaten/Kota menerima hasil pengawasan dan diserahkan kepada Pemerintah Pusat.

Pengawasan supra Desa yang lain adalah audit investigatif dari Badan Pemeriksa Keuangan (BPK) dan Badan Pengawasan Keuangan dan Pembangunan (BPKP). Ber- 
dasarkan UU No. 15 tahun 2004 tentang Pemeriksaan Pengelolaan dan Tanggung Jawab Keuangan Negara dimana keuangan desa yang berasal dari pemerintah pusat dan pemerintah daerah termasuk ke dalam kategori keuangan negara karena sumbernya berasal dari APBN dan APBD. Kewenangan BPKP diberikan oleh PP No. 60 Tahun 2008 tentang Sistem Pengendalian Intern Pemerintah untuk melakukan pengawasan pemakaian keuangan desa yang bersumber dari APBN dan APBD.

Pasal 55 dan Pasal 82 UU Desa memberikan fungsi Pengawasan kepada BPD terhadap hasil kerja Kepala Desa dengan tanggapan dari pertanggungjawaban Kepala Desa dan laporan masyarakat kepada BPD. BPD berkewenangan terhadap pengawasan kepada perangkat desa dalam penggunaan uang desa.

Pasal 82 UU Desa menentukan Pengawasan dari masyarakat. Hal tersebut dijamin haknya untuk mengetahui dan memberikan komentar laporan pertanggungjawaban kepala desa. Pasal 26, 55, 82 UU Desa menentukan pengawasan publik kepada pemerintah desa dalam menggunakan keuangan desa disertai dengan keharusan desa mempunyai sistem informasi desa sebagai pelaksanaan hak masyarakat dalam memperoleh informasi.

\section{Kesalahan Pengelolaan Keuangan Desa Berpotensi Menimbulkan Kerugian Keuan- gan Negara}

\section{Definisi Kerugian Keuangan Negara}

Kerugian negara menurut Pasal 1 angka 15 Undang-Undang Nomor 15 Tahun 2006 tentang Badan Pemeriksa Keuangan diartikan sebagai kekurangan uang, surat berharga, dan barang, yang nyata dan pasti jumlahnya sebagai akibat perbuatan melawan hukum baik sengaja maupun lalai. Penjelasan Pasal 32 ayat (1) Undang-Undang Nomor 31 Tahun 1999 tentang Pemberantasan Tindak Pidana Korupsi dinyatakan bahwa yang dimaksud dengan "secara nyata telah ada kerugian keuangan negara" adalah kerugian yang dapat dihitung jumlahnya berdasarkan hasil audit instansi yang berwenang atau akun- tan publik yang ditunjuk (Atmojo, Ma'ruf \& Djauhari, 2017: 700).

Akibat dari perbuatan Korupsi dapat menimbulkan kerugian keuangan negara berupa actual loss atau potential loss. Actual loss terjadi karena kerugian negara yang benar-benar sudah terjadi. Sedangkan potential loss terjadinya kerugian keuangan Negara sebagai akibat adanya perbuatan melawan hukum. Penentuan kerugian keuangan negara dalam tindak pidana korupsi lebih menekankan kepada kerugian yang bersifat nyata (actual loss) (Setiawan \& Ma'ruf, 2017: 519).

Korupsi mengidentifikasikan kejahatan yang bersifat laten yang berpotensi untuk merugikan dan membahayakan negara, sebagaimana tindak pidana lainnya yang identik dengan ancaman terhadap penegakan hukum keadilan dan kemanusiaan. Pelaku biasanya tidak sendiri dalam menjalankan aksinya, tindakan korupsi berjamaah akan saling menyandera satu sama lain dan memungkinkan saling melindungi antaraktor dalam kelembagaan. Dugaan kuat akan membentuk sebuah jaringan korupsi dalam sebuah lembaga atau instansi (Rahman, Dkk, 2018: 31).

Pasal 1 angka 22 UU Perbendaharaan Negara dan Pasal 1 angka 15 UU No. 15 tahun 2006 tentang Badan Pemeriksa Keuangan memberikan definisi, "Kerugian Negara/ Daerah adalah kekurangan uang, surat berharga, dan barang, yang nyata dan pasti jumlahnya sebagai akibat perbuatan melawan hukum baik sengaja maupun lalai." Konsep tersebut seperti Penjelasan Pasal 32 ayat (1) UU Tipikor yang menyebut terjadi kerugian negara yang bisa dihitung oleh instansi yang memiliki kewenangan atau akuntan publik yang ditunjuk. Oleh karena itu, BPK dan BPKP dalam melakukan perhitungan kerugian Negara berdasarkan pada ketentuan tersebut (Setiawan \& Ma'ruf, 2017: 520-521).

UU No. 31 tahun 1999 tentang Pemberantasan Tidak Pidana Korupsi juncto UU No 20 tahun 2001 menjadi landasan untuk upaya pencegahan dan pemberantasan tindak pidana korupsi mengalami perubahan mendasar. Perubahan pertama secara konstitusional terjadi pada 24 Juli 2006, Mahka- 
mah Konstitusi melalui putusan No. 003/ PUU-IV/2006 menyatakan norma penjelasan Pasal 22 Ayat (1) UU Tindak Pidana Korupsi bertentangan dengan konstitusi sehingga menjadi delik formil. Perubahan kedua secara konstitusional terjadi pada 25 Januari 2017, Mahkamah Konstitusi melalui Putusan No. 25/PUU-XIV/2016 menafsirkan frasa kata "dapat" dalam rumusan Pasal 2 dan Pasal 3 UU Tipikor bertentangan dengan konstitusi sehingga "tidak mengikatnya" kata "dapat" berkonsekuensi terhadap Pasal 2 dan Pasal 3 UU Tipikor menjadi delik materiil. Penulisan kata "dapat" dalam Pasal 2 ayat (1) dan Pasal 3 UU Tipikor menimbulkan ketidakpastian hukum dan bertentangan dengan jaminan bahwa setiap orang berhak atas rasa aman dan perlindungan dari ancaman ketakutan sesuai Pasal 28G ayat (1) UUD 1945. Kata "dapat" ini bertentangan juga dengan prinsip perumusan tindak pidana yang harus memenuhi prinsip hukum harus tertulis (lex scripta), menafsirkan seperti yang dibaca (lex stricta), dan larangan multitafsir (lex certa). Dengan demikian Pasal 2 ayat (1) dan Pasal 3 UU Tipikor tentang penerapan unsur merugikan keuangan negara telah bergeser dengan menitikberatkan adanya akibat (delik materil). Unsur merugikan keuangan negara tidak dipahami sebagai perkiraan (potential loss), tetapi harus dipahami kerugian yang benarbenar terjadi atau nyata (actual loss) (Setiawan \& Ma'ruf, 2017: 521).

Berbagai pendekatan dalam penghitungan kerugian keuangan Negara menjadi acuan para auditor, Theodorus M. Tuanakotta merumuskan dalam bukunya "Menghitung Kerugian Keuangan Negara Dalam Tindak Pidana Korupsi". Penghitungan kerugian keuangan Negara dimaksud adalah kerugian total ( Total Loss ), kerugian secara keseluruhan dengan penyesuaian, kerugian bersih, harga yang wajar, opportunity cost, interest yang menjadi Unsur Kerugian Keuangan Negara (Setiawan \& Ma'ruf, 2017: 520).

BPK dan BPKP dalam menentukan perhitungan kerugian keuangan Negara dengan menggunakan lima konsep atau cara penghitungan kerugian keuangan negara adalah kerugian keseluruhan berdasarkan penye- suaian, sisa harga pokok produksi, sisa nilai komparasi tertentu, pendapatan negara masuk menjadi kepemilikan negara tetapi tidak disetorkan kepada negara, pembelanjaan yang tidak berdasarkan anggaran, digunakan demi kepentingan pribadi (Arif Setiawan \& Umar Ma'ruf, 2017: 520).

Penafsiran keuangan negara dalam arti sempit bertujuan memberikan tafsiran anggaran negara tersebut untuk memahami pengelolaan dan penggunaan anggaran tersebut, artinya penggunaan dan melaporkan anggaran negara sesuai regulasi keuangan negara. Keuangan negara dalam arti luas apabila pendekatannya dilakukan dengan menggunakan cara penafsiran sistematis dan teleologis untuk mengetahui sistem pengawasan atau pemeriksaan pertanggungjawaban yakni termasuk di dalamnya keuangan yang berada APBN, APBD, BUMN/D dan pada hakikatnya seluruh kekayaan Negara merupakan objek pemeriksaan dan pengawasan (Atmadja, 2009: 99). Keuangan desa adalah keuangan negara. Oleh karena itu, Kerugian anggaran negara yang benar-benar terjadi atau nyata (actual loss), karena tidak berdasarkan peraturan perundang-undangan merupakan perbuatan korupsi.

\section{Asas Pengelolaan Keuangan Desa}

Penggunaan keuangan desa sangat erat dengan prinsip-prinsip berhubungan dekat dengan good governance dan HAM, antara lain partisipatif, akuntabel, transparan, taat hukum, dan manfaat. Partisipatif dimaksud adalah penyelenggaraan keuangan desa harus mengikutsertakan masyarakat desa, tahap perencanaan dan pelaksanaan evaluasi keuangan desa. Akuntabel adalah mencerminkan dari tanggung jawab pengelolaan dan pengendalian keuangan desa untuk mencapai cita-cita yang ditentukan. Transparan adalah membuka akses seluas-luasnya sehingga masyarakat desa mendapatkan informasi utuh tentang keuangan desa. Taat hukum penyelenggaraan keuangan desa wajib harus sesuai dengan regulasi. Kemudian Asas manfaat adalah peggunaan anggaran desa memprioritaskan kebutuhan masyarakat desa dan hakhak dasar masyarakat desa (Michael, 2017: 
135).

Pengelolaan keuangan desa, dikelola dalam waktu 1 tahun anggaran yaitu mulai tanggal 1 januari sampai 31 Desember. Asasasas tersebut diantaranya ada tiga yaitu (Astuti, 2016: 5-6): transparansi adalah prinsip keterbukaan untuk memudahkan masyarakat mengetahui dan mendapatkan akses informasi seluas-luasnya tentang keuangan daerah. Dengan adanya transparansi menjamin kebebasan setiap orang untuk memperoleh informasi tentang pelaksanaan pemerintahan, dalam hal ini informasi tentang kebijakan, proses pembuatan dan pelaksanaan, juga hasil-hasil yang dicapai. Transparansi adalah kebijakan terbuka dalam melakukan pengawasan. Sedangkan informasi adalah aspek kebijakan pemerintah yang mudah diakses oleh publik. Keterbukaan informasi akan membuahkan persaingan politik yang sehat, toleran dan kebijakan dibuat berdasarkan pada kepentingan publik.

Transparansi merupakan hal terpenting dalam melaksanakan fungsi-fungsi pemerintahan dalam rangka memenuhi amanat dari rakyat. Pemerintah mempunyai kewenangan penentuan penting yang berpengaruh kepada sebagian besar orang, pemerintah harus membuka akses seluas-luasnya secara utuh mengenai pekerjaan yang telah dikerjakan. Transparansi bisa menggunakan beberapa parameter yaitu ketentuan yang menjamin sistem keterbukaan dan standarisasi dari pelayanan masyarakat, ketentuan yang memfasilitasi pertanyaan-pertanyaan publik tentang macam-macam kebijakan dan pelayanan publik, maupun proses-proses di dalam sektor publik, mekanisme memfasilitasi pelaporan, penyebaran informasi, penyimpangan aparat publik dalam pelayanan.

Akuntabilitas adalah kewajiban memberikan pertanggungjawaban atau menjawab dan menerangkan hasil kerja dan perbuatan seseorang badan hukum pimpinan suatu organisasi kepada orang yang memiliki hak atau mempunyai kewenangan meminta keterangan atau pertanggungjawaban. Pelaksanaan akuntabilitas di lingkungan instansi pemerintah, perlu memeperhatikan tentang keterikatan pimpinan dan seluruh staf instan- si untuk melakukan misi secara bertanggungjawab, sistem tersebut menjamin fungsi sumber-sumber daya secara berkelanjutan sesuai regulasi, menampilkan performa sasaran dan tujuan yang sudah berjalan, mempunyai orientasi dengan capaian visi dan misi sesuai dengan manfaat yang didapat, harus menyampaikan apa adanya, objektif, terbuka dan terinovasi sebagai pengukur perubahan manajemen pemerintahan dalam bentuk pembaharuan metode dan teknik parameter kinerja dan menyusun laporan akuntabilitas.

Partisipatif adalah mengajak masyarakat terlibat dengan aktif proses pembangunan desa. Partisipasi adalah setiap warga negara mempunyai hak suara dalam membuat keputusan, secara langsung dan intermediary yang mewakili kepentingan masing-masing. Partisipasi tersebut dibangun atas dasar kebebasan berasosiasi, berbicara harus ikut serta secara konstruktif. Keterlibatan publik dalam penentuan kebijakan pemerintahan memicu terpenuhinya prinsip akuntabilitas dari pemerintah desa. Perencanaan anggaran mengikutsertakan masyarakat sangat esensial untuk mencegah penyimpangan oleh pemerintah desa.

\section{Risiko Keuangan Desa}

BPKP memprediksi Risiko keuangan desa yang berpotensi mengakibatkan kerugian keuangan negara yang akan terjadi di antaranya (Warta Pengawasan BPKP, 2015: 5-6)

1. Risiko Tingkat Entitas Pemerintah Desa

a. Program dan Kegiatan pada RPJMDes, RKPDes, dan APBDes tidak memprioritaskan aspirasi/kebutuhan masyarakat desa. Penetapan program dan kegiatan dengan prioritas kepentingan golongan atau kelompok, bukan kepentingan rakyat banyak. Program dan kegiatan pada RPJMDes dan RKPDes tidak sesuai aspirasi dan kebutuhan desa mengakibatkan pembangunan desa tidak dapat dirasakan mayoritas masyarakat desa.

b. Ketidaksanggupan penyelenggaraan Siklus Pengelolaan Keuangan Desa sesuai regulasi. Sesuai UU No. 6 Tahun 2014 tentang Desa, PP No. 43 tahun 2014 
tentang Keuangan Desa, dan Permendagri No 113 tahun 2014 tentang Pengelolaan Keuangan Desa, siklus keuangan desa meliputi perencanaan (MusrenbangDes, RPJMDes - setiap 6 tahun, RKPDes), penganggaran (APBDes), Pelaksanaan, Pelaporan (Laporan Realisasi APBDes Semester1 dan 2), dan Pertanggungjawaban (Laporan Penyelenggaraan Pemerintahan Desa). Kegagalan Pemerintah Desa menyelenggarakan proses tersebut sesuai dengan ketentuan yang berlaku, tidak berdasarkan jadwal atau penetapan anggaran tidak sesuai.

c. Ketidaktepatan waktu penyusunan Laporan Pelaksanaan Pemerintah Desa, termasuk Laporan Pertanggungjawaban RealisasiPelaksanaanAPBDes. Penyusunan laporan yang terlambat. Ketidakberhasilan tersebut mengakibatkan turunnya public trust kepada pemerintahan desa.

d. Penggunaan Aset Desa inefisien dan tidak efektif, penggunaan aset desa (kantor, tanah desa, paralatan) belum sesuai penggunaannya. Kesalahan tersebut mengakibatkan keuangan desa menjadi boros dan pembangunan desa tidak tercapai.

2. Risiko Fraud (Kecurangan)

Beberapa risiko kecurangan (fraud) yang dapat terjadi dalam pengelolan keuangan desa, antara lain:

a. Penggunaan Kas Desa secara tidak sah. Risiko tersebut adalah penyalahgunaan kas desa secara tidak sah oleh aparat pemerintah. Pencurian mengakibatkan kemampuan pemerintah desa dalam menjalankan tugas pokok dan fungsinya.

b. Mark up Pengadaan Barang dan Jasa adalah menaikan harga beli barang/ jasa dari harga wajarnya, setelah itu pengembalian sejumlah kas kepada aparat terkait merupakan bentuk kecurangan yang biasa terjadi. Dalam kondisi sistem pengendalian pemerintahan desa yang tidak siap.

c. Penggunaan Aset Desa untuk kepentingan pribadi aparat desa tanpa izin. Aset desa, berupa sarana kantor, tanah desa, peralatan kantor ataupun kendaraan kantor seharusnya digunakan untuk mendukung tugas pokok dan fungsi pemerintahan desa. Akan tetapi peralatan tersebut digunakan untuk kepentingan pribadi, atau bahkan dimiliki secara tidak sah.

d. Pungutan Liar (illegal Gratuities) Layanan Desa Pungutan Liar adalah pungutan yang tidak ada aturannya yang dibebankan kepada masyarakat oleh instansi pemerintah. Dalam hal ini melestarikan memberikan uang tip, hal tersebut menjadi risiko yang sangat tinggi terjadinya. Hal tersebut menimbulkan ketidaknyamanan dalam pelayanan masyarakat.

\section{Risiko Tingkat Aktivitas}

Setiap kegiatan desa memiliki risiko. Kegiatan utama Pemerintahan Desa, seperti penyusunan Laporan Penyelenggaraan Pemerintah Desa, termasuk Laporan Pertanggungjawaban Realisasi Pelaksanaan APPBDes, Pemungutan Pendapatan Asli Desa, Pembinaan kepada masyarakat, Pengelolaan Aset Desa, atau. Semua aktivitas tersebut mempunyai risiko-risiko berdasarkan ciri-ciri dan tujuan masing-masing aktivitas. Pengambilan Pendapatan Asli Desa dengan tujuan memungut dan mengumpulkan pendapatan asli desa dengan dasar regulasi, mempunyai risiko yaitu, ketidaktepatan nilai tagihan. Pemerintah desa menyelenggarakan pengambilan Pendapatan Asli Desa yaitu hasil, atau hasil Aset (Tambatan Perahu, Pasar Desa, Tempat Pemandian Umum atau Jaringan Irigasi) dalam melakukan mengambil manfaatnya ada risiko ketidaktepatan penetapan tagihan yang masuk ke Kas Desa. Risiko tersebut berpotensi mengurangi potensi pendapatan desa atau adanya kerugian keuangan desa.

Penerimaan Kas tidak dimasukan ke Kas Desa mengurangi pendapatan desa yang digunakan untuk membangun desa dan menguntungkan secara pribadi petugas pemerintahan.

Berpijak pada resiko keuangan desa yang telah diuraikan diatas, penulis mengulas empat kasus korupsi dana desa yang terjadi, karena penyalahgunaan kewenangan untuk memperkaya diri sendiri yang mengakibatkan kerugian keuangan negara. Kasus-kasus dibawah terjadi sesuai dengan prediksi BPKP 
yaitu terjadinya resiko kecurangan menggunakan Kas Desa secara tidak sah. Kasus-kasus tersebut antara lain:

Kawardin Purba divonis empat tahun penjara karena terbukti melakukan korupsi dana desa sebesar Rp 203 juta. Senin, 3 September 2018, Kepala Desa Pangulu Nagori di Pamatangsinaman, Kecamatan Dolokpardamean, Kabupaten Simalungun, Sumatera Utara, ini terbukti melanggar Pasal 2 ayat (1) jo Pasal 18 Undang-undang Nomor 31 tahun 1999 jo Undang-Undang Nomor 20 tahun 2001. Terdakwa telah melakukan korupsi sebesar Rp 203 juta sehingga divonis empat tahun penjara, melalui Syafril Ketua Majelis Hakim Pengadilan Negeri Kota Medan. Terdakwa juga harus membayar denda Rp 200 juta dengan subsider dua bulan kurungan, dan membayar uang pengganti kerugian negara sebesar Rp 203 juta. Uang Dana Desa Rp 329 Juta raib. Jika terdakwa tidak sanggup membayarnya dalam jangka waktu sebulan, harta bendanya akan disita negara. Apabila tidak mencukupi maka diganti dengan pidana penjara selama dua tahun (Leanda, 2018).

Kades Banjarsari Kecamatan Jetis, Andi Mulyono (40) ditahan Kejaksaan Negeri (Kejari) Mojokerto. Kades Andi diduga melakukan korupsi uang desa senilai Rp 296 juta. Modusnya, tersangka membuat 2 proyek pembangunan fiktif. Andi diduga melakukan korupsi terhadap APBDes Banjarsari tahun anggaran (TA) 2015. Tersangka saat itu membuat 2 proyek fiktif agar bisa menikmati uang rakyat. Yakni proyek pembangunan pavingisasi di Dusun Banjarsari dan pembangunan gapura masuk desa di Dusun Jeruk Kidul. Tak satu pun proyek tersebut dikerjakan tersangka. Padahal anggaran telah dicairkan. Hasil audit inspektorat, kerugian negara akibat dua proyek fiktif tersebut Rp 296.413.355. Akibat perbuatannya, kata Agus, Andi dijerat dengan Pasal 2 ayat (1) atau Pasal 3 UU RI No 20 tahun 2001 tentang Pemberantasan Tindak Pidana Korupsi. "Ancaman hukumannya maksimal 20 tahun penjara atau hukuman mati (Budianto, 2018).

Kepala Desa (Kades) Sempol, Maospati, Magetan, Ngadeni ditahan Kejaksaan setempat. Tersangka diduga korupsi kas desa yang dipimpin selama 3 tahun. Kepala Kejaksan Negeri Magetan Atang Pujiyanto menyampaikan ada beberapa kegiatan tidak sesuai yang dilakukan dengan anggaran yang ada. Sehingga, setelah kita lakukan pemeriksaan kunjungan langsung ke lapangan bersama pihak PU, ternyata hasilnya ada beberapa pekerjaan proyek yang tidak di laksanakan. Dari hasil pemeriksaan tim penyidik, Kades yang merupakan pecatan TNI ini terbukti merugikan keuangan Desa Sempol lebih dari Rp 300 juta. Ada lima proyek fisik APBDes tahun 2014, 2015 dan 2016 yang kesemuanya belum selesai. Atang mengatakan, selain penyelewengan anggaran proyek fisik, tersangka juga menggunakan modus korupsi lain. Kades Sempol meminta uang Rp 200 juta dari Bendahara Desa tanpa memberikan penjelasan peruntukannya. Pelaksana Harian (PLH Kasi Pidsus Kejari Magetan Mohamat Safir menyatakan tersangka dijerat dengan Pasal 2 dan 3 UU Pemerantasan Tindak Pidana Korupsi. Ancaman hukumannya 20 tahun penjara (Harianto, 2018).

Polres Ciamis menetapkan Mantan Kepala Desa Danasari Yayat (50) Kecamatan Cisaga Kabupaten Ciamis, Jawa Barat, sebagai tersangka atas dugaan tindak pidana korupsi tiga sumber keuangan desa, yakni Dana Desa, Dana Alokasi Khusus (DAK) dan Alokasi Dana Desa (ADD) serta Banprov untuk peningkatan infrastruktur dasar perdesaan dan tunjangan penghasilan aparatur. Kapolres Ciamis AKBP Bismo Teguh Prakoso mengatakan tindak pidana korupsi dilakukan tersangka saat menjadi Kepala Desa Danasari pada 2015 dan 2016 dengan total kerugian negara sebesar Rp 105 juta. Uang itu digunakan untuk kepentingan pribadi. Total sumber keuangan desa itu dari Pemda, Pemprov dan Pusat dengan total Rp 800 juta. Saat praktik pembangunan jalan ternyata tidak sesuai spesifikasi, Setelah mendapat laporan dari masyarakat, Satreskrim melakukan penyelidikan di tahun 2017, melakukan pemeriksaan fisik dan audit. Tersangka terbukti melakukan tindak pidana korupsi. Kami juga telah meminta keterangan saksi ahli dan saksi-saksi lainnya. Tersangka melakukannya sendiri untuk kepentingan pribadi. Sejauh ini tersangka tidak mampu mengembalikan uang hasil korupsi. 
Akibat perbuatannya tersangka dijerat dengan Pasal 2 ayat (1) dan atau Pasal 3 Undangundang nomor 31 tahun 1999, sebagaimana diubah dengan undang-undang nomor 20 tahun 2001 tentang pemberantasan tindak pidana korupsi. Tersangka terancam hukuman minimal 4 tahun maksimal 20 tahun penjara (Hermansyah, 2018).

Dari pemaparan tentang kerugian keuangan negara yang terjadi dalam pengelolaan dana desa yang benar-benar sudah terjadi atau nyata (actual loss), karena perbuatan penyalahgunaan kewenangan untuk memperkaya diri sendiri tidak berdasarkan peraturan perundang-undangan merupakan perbuatan korupsi. Korupsi yang terjadi di Simalungun, Mojokerto, Magetan dan Ciamis yang diangkat dalam penelitian ini tampak bahwa halhal tersebut terjadi karena adanya penyalahgunaan kewenangan oleh kepala desa untuk memperkaya diri sendiri berdasarkan Pasal 2 dan Pasal 3 Undang-Undang No. 31 Tahun 1999 juncto Undang-Undang No. 20 Tahun 2001 tentang Pemberantasan Tindak Pidana Korupsi sebagaimana disangkakan, didakwakan, dan yang telah terbukti di pengadilan. Kerugian keuangan yang terjadi merupakan kesalahan pengelolaan keuangan desa yang merupakan keuangan negara.

Pedoman Pengelolaan keuangan desa terpadu berdasarkan Pasal 93 ayat (1) Peraturan Pemerintah Nomor 43 Tahun 2014 tentang Peraturan Pelaksana Undang-Undang Nomor 6 Tahun 2014 tentang Desa meliputi Perencanaan, Pelaksanaan, Penatausahaan, Pelaporan dan Pertanggungjawaban. Dalam 4 kasus korupsi dana desa yang terjadi di atas menunjukan empat Kepala Desa tidak bisa mempertanggungjawabkan dalam Pelaporan dan Pertanggungjawaban Keuangan Desa. Karena korupsi yang dilakukan dengan cara memperkaya diri sendiri tentunya tidak bisa dipertanggungjawabkan.

Kasus-kasus korupsi dana desa yang terjadi telah melanggar asas pengelolaan keuangan desa yaitu akuntabilitas yang seharusnya diterapkan oleh pemerintahan desa dalam pengelolaan keuangan desa untuk mencegah terjadinya kerugian keuangan negara. Akuntabilitas (accountability) adalah kewajiban untuk memberikan pertanggungjawaban atau menjawab dan menerangkan kinerja dan tindakan seseorang badan hukum pimpinan suatu organisasi kepada pihak yang memiliki hak atau berkewanangan untuk meminta keterangan atau pertanggungjawaban.

Risiko keuangan desa yang diprediksikan oleh BPKP yang telah penulis uraikan berpotensi mengakibatkan kerugian keuangan negara telah terjadi di Simalungun, Mojokerto, Magetan dan Ciamis. Prediksi tersebut seharusnya ditindaklanjuti dengan mengevaluasi sistem pengawasan yang tidak berjalan kepada kepala desa serta perangkatnya dalam mengelola keuangan desa, pengawasan melekat seharusnya dilakukan oleh Badan Perwakilan Desa (BPD). Koordinasi antar Kementerian Keuangan, Kementerian Dalam Negeri, dan Kementerian Desa dan Transmigrasi perlu dilakukan untuk mencegah terjadinya kerugian keuangan negara.

\section{SIMPULAN}

Pengaturan dan pengelolaan keuangan desa menyimpulkan bahwa keuangan desa merupakan bagian dari keuangan negara. Karena keuangan daerah merupakan bagian dari keuangan Negara. Desa sebagai kesatuan pemerintahan terkecil dalam pemerintahan Indonesia memiliki sistem keuangan tersendiri yang terintegral ke dalam pendapatan asli desa dan merupakan bagian dari APBN. Pasal 73, Pasal 75 Undang-Undang No. 6 Tahun 2014 Bab VIII tentang Keuangan Desa dan Aset Desa menentukan Kepala Desa memusyawarahkan dan menetapkan APBDesa. Kepala Desa adalah pemegang kekuasaan pengelolaan Keuangan Desa dan menguasakan sebagian kekuasaannya kepada perangkat Desa. Tata kelola pemerintahan desa yang baik, yang memiliki tiga pilar utama yaitu transparansi, akuntabilitas dan partisipatif. Pengelolaan keuangan desa berdasarkan Pasal 93 ayat (1) Peraturan Pemerintah Nomor 43 Tahun 2014 tentang Peraturan Pelaksana Undang-Undang Nomor 6 Tahun 2014 tentang Desa meliputi Perencanaan, Pelaksanaan, Penatausahaan, Pelaporan dan Pertanggungjawaban. Undang-Undang Desa 
meletakkan prinsip dasar untuk penyelenggaraan, pengawasan dan pemantauan pembangunan desa yang meliputi pengawasan oleh supra-desa (downward accountability) yaitu pemerintah pusat dalam hal ini Kementerian Dalam Negeri RI, Kementerian Desa dan Transmigrasi RI dan Kementerian Keuangan RI. Dalam operasionalnya, pengawasan oleh pemerintah kabupaten/kota menjadi tanggung jawab bupati/walikota. Fungsi pengawasan tersebut didelegasikan oleh bupati/ kota kepada camat dan juga Inspektorat Kabupaten/Kota. Pengawasan supra Desa lainnya adalah pengawasan dari Badan Pemeriksa Keuangan (BPK) dan Badan Pengawasan Keuangan dan Pembangunan (BPKP), pengawasan oleh lembaga desa dan pengawasan dari masyarakat (upward accountability).

Kerugian keuangan negara yang terjadi dalam pengelolaan dana desa di Simalungun, Mojokerto, Magetan dan Ciamis menyimpulkan kerugian yang benar-benar sudah terjadi atau nyata (actual loss), karena penyalahgunaan kewenangan yang dilakukan oleh kepala desa untuk memperkaya diri sendiri tidak berdasarkan peraturan perundang-undangan. Kerugian keuangan yang terjadi merupakan kesalahan pengelolaan keuangan negara. Asas pengelolaan keuangan desa yaitu akuntabilitas tidak diterapkan oleh pemerintahan desa, sehingga terjadi penyalahgunaan kewenangan oleh kepala desa. Risiko keuangan desa yang diprediksikan oleh BPKP menyimpulkan berpotensi mengakibatkan kerugian keuangan negara. Kasus-kasus dibawah terjadi

Karena penyalahgunaan kewenangan pengelolaan dana desa di Simalungun, Mojokerto, Magetan dan Ciamis sesuai dengan prediksi BPKP yaitu terjadinya resiko kecurangan menggunakan Kas Desa secara tidak sah (Theft of Cash on Hand) yang mengakibatkan kerugian keuangan negara. Prediksi tersebut seharusnya ditindaklanjuti dengan mengevaluasi sistem pengawasan yang tidak berjalan kepada kepala desa serta perangkatnya dalam mengelola keuangan desa, pengawasan melekat seharusnya dilakukan oleh Badan Perwakilan Desa (BPD), sehingga kepala desa tidak melakukan tindak pidana korupsi. Selain itu, koordinasi antar Kementerian Keuangan, Kementerian Dalam Negeri, dan Kementerian Desa dan Transmigrasi perlu dilakukan untuk mencegah terjadinya kerugian keuangan negara.

\section{DAFTAR PUSTAKA}

Asshiddiqie, J. (2007). Pokok-Pokok Hukum Tata Negara Indonesia Pasca Reformasi. Bhuana Ilmu Populer.

Asshiddiqie, J. (2007). Gagasan Konstitusi Sosial, Jakarta: LP3ES.

Astuti, T. P., \& Yulianto, Y. (2016). Good Governance Pengelolaan Keuangan Desa Menyongsong Berlakunya Undang-Undang No. 6 Tahun 2014. Berkala Akuntansi dan Keuangan Indonesia, 1(1): 5-6.

Atmadja, A. P. S. (2009). Keuangan publik dalam perspektif hukum: teori, kritik, dan praktik. Rajawali Pers.

Atmojo, B. P. (2017). Eksistensi Penentuan Kerugian Negara Dalam Penyidikan Tindak Pidana Korupsi. Jurnal Hukum Khaira Ummah, 12(4), 695-704.

Budianto, E.E. (2018, Juli 4). Kasus Korupsi Dana Desa, Kades di Mojokerto Balikin Uang Rp 196 Juta. detikcom. diakses dari https://news.detik.com/ berita-jawa-timur/d-4098168/kasus-korupsidana-desa-kades-di mojokerto-balikin-uangrp-196-juta. 30 Oktober 2018

Harianto, S. (2018, September 10). Diduga Korupsi Kas Desa, Kades di Magetan Ini Dibui. detikcom. diakses dari https://news.detik.com/berita-jawa-timur/d-4205851/diduga-korupsi-kas-desakades-di-magetan-ini-dibui. 30 Oktober 2018.

Hermansyah, D. (2018, Juli 16). Mantan Kades Ciamis Jadi Tersangka Korupsi Dana Desa. detikcom. diakses dari https://news.detik.com/beritajawa-barat/d-4117587/mantan-kades-ciamisjadi-tersangka-korupsi-dana desa? . 30 Oktober 2018.

Khoiriah, S., \& Meylina, U. (2017). Analisis sistem pengelolaan dana desa berdasarkan regulasi keuangan desa. Masalah-Masalah Hukum, 46(1), 2029.

Leanda, M. (2018, September 3). Korupsi Dana Desa Rp 203 Juta, Kades di Simalungun Dipenjara 4 Tahun. Kompas. diakses dari https://regional. kompas.com/read/2018/09/03/22571311/korupsi-dana-desa-rp-203-juta kades-di-simalungun-dipenjara-4-tahun. 30 Oktober 2018.

Meutia, I., \& Liliana, L. (2017). Pengelolaan Keuangan Dana Desa. Jurnal Akuntansi Multiparadigma, 8(2), 336-352.

Michael, D. (2017). Pengelolaan Keuangan Desa Dalam Perspektif Hak Asasi Manusia: Studi Terhadap Pengelolaan Keuangan Desa Di Desa Sei Baharu, Kecamatan Hamparan Perak, Kabupaten Deli Serdang, Provinsi Sumatera Utara. Jurnal HAM, 8 (2): 135

Muin, F. (2014). Otonomi Daerah Dalam Persepektif 
Pembagian Urusan Pemerintah-Pemerintah Daerah Dan Keuangan Daerah. Fiat Justisia Jurnal Ilmu Hukum, 8(1), 75.

Paratama, F. (2018). Evaluasi Pelaksanaan Peraturan Daerah Tentang Alokasi Dana Desa. Jurnal Bilancia, 12(1), 34.

Rahman, F., Baidhowi, A., Sembiring, R.A. (2018). Pola Jaringan Korupsi di Tingkat Pemerintah Desa (Studi Kasus Korupsi DD dan ADD Tahun 20142015 di Jawa Timur). Integritas, 4(1), 31.

Saidi, M.D. (2008). Hukum Keuangan Negara Edisi Revisi, Jakarta: Rajawali Pers.
Setiawan, A., \& Ma'ruf, U. (2017). Penerapan Unsur Dapat Merugikan Keuangan Negara Dalam Tindak Pidana Korupsi. Jurnal Hukum Khaira Ummah, 12(3): 519-524.

Sumbu, T. (2010). Hubungan Pemerintah Pusat dengan Pemerintah Daerah dalam Kerangka Pengelolaan Keuangan Negara dan Daerah. Ius Quia lustum Law Journal, 17(4), 567-588.

Soekanto, S., \& Mamudji, S. (2001). Penelitian hukum normatif: Suatu tinjauan singkat. RajaGrafindo Persada.

Warta Pengawasan BPKP. (2013, September). Kawal Keuangan Desa, Majalah BPKP, 22: 5-6. 